\title{
Erratum to: Thermal diffusivity identification by 2 nd derivative analysis of transient temperature profile
}

\author{
${\text { Damien } \text { Meresse }^{1} \text { (I) } \cdot \text { Souad Harmand }}^{1} \cdot$ Ali Grine $^{2}$
}

Published online: 31 March 2016

(C) Akadémiai Kiadó, Budapest, Hungary 2016

\section{Erratum to: J Therm Anal Calorim DOI 10.1007/s10973-016-5273-5}

Unfortunately, some elements about the 3rd author Ali Grine have not been inserted in the published original article.

1. The affiliation of the third author is wrong and must be replaced by: "Faculté des Sciences de l'Ingénieur, Université M'Hamed Bougara, 35000 Boumerdes, Algeria”.
2. For any information about the development of the analytical solution, please contact the third author Ali Grine by email at aligrine@yahoo.fr.

The online version of the original article can be found under doi:10.1007/s10973-016-5273-5.

Damien Meresse

damien.meresse@univ-valenciennes.fr;

dmeresse@univ-valenciennes.fr

Ali Grine

aligrine@yahoo.fr

1 LAMIH UMR CNRS 8201, University of Valenciennes, 59313 Valenciennes, France

2 Faculté des Sciences de l'Ingénieur, Université M'Hamed Bougara, 35000 Boumerdes, Algeria 